J. XIANG ${ }^{1}$ and Yu. JIANG ${ }^{1}$

\title{
LONG-TERM VIDEO ELECTROENCEPHALOGRAPHY AND ELECTROCORTICOGRAPHY IN TEMPORAL LOBE EPILEPSY-RELATED SURGERY
}

\author{
Received January 5, 2014
}

Eighty-eight patients suffering from temporal lobe epilepsy (TLE) underwent epilepsy-related surgery monitored by preoperative long-term video EEG (VEEG) and intraoperative ECoG. The patterns, location, and spatial distribution of epileptiform discharges recorded by VEEG and ECoG were analyzed and compared. In 56 patients, frequent focal epileptiform discharges were recorded by VEEG at one side of the temporal lobe and identified in the temporal lobe and interior frontal gyrus by ECoG. Epileptiform discharges were recorded by VEEG at both sides of the temporal lobe in 20 patients and by all recording electrodes at one side of the temporal lobe in 12 patients. In these patients, epileptiform discharges were identified by ECoG in the left sylvian gyrus of the temporal lobe and in the inferior and middle frontal gyri. Spatial distributions of epileptiform discharges were adequately identified by ECoG in $52(59 \%)$ patients, with a consistency of $>80 \%$ in $24(27 \%)$ patients, and with a consistency of $60-80 \%$ in $12(14 \%)$ patients, compared with that estimated by VEEG. Patients remained seizure-free in $72(81.8 \%)$ cases; their state was improved significantly in $12(13.6 \%)$ cases and remained unimproved in $4(4.5 \%)$ cases. Our data suggest that ECoG possesses certain advantages over VEEG in accurate localization of the epileptogenic foci and, thus, is important for surgical treatment of TLE.

Keywords: long-term video electroencephalography, electrocorticography, temporal lobe epilepsy, surgical treatment.

\section{INTRODUCTION}

Epilepsy is one of the most common neurological diseases in the world; about 40 to 50 million people suffer from this pathology. About 30 million patients do not receive any treatment. Temporal lobe epilepsy, TLE, a rather frequent type of epilepsy in the clinics, accounts for about $25 \%$ of the total number of patients with epilepsy, and about $60 \%$ of medically refractory epilepsy cases are treated with epilepsy-related surgery $[1,2]$. This type of effective treatment of TLE was first used in 1950s [3]. Up to date, epilepsy surgery has become the best choice for the treatment of TLE and demonstrated clear advantages in the efficacy, as compared to the best medical therapy [4].

The goal of epilepsy surgery is to permanently disrupt the epileptogenic networks and achieve freedom from seizures without causing serious

${ }^{1}$ Department of Neurosurgery, Second Xiangya Hospital of the Central South University, Changsha, China.

Correspondence should be addressed to

J. Xiang (e-mail: gghfyf@hotmail.com). neurological or cognitive dysfunctions. Unfortunately, only $67-81 \%$ of patients who underwent such surgical intervention remain seizure-free [5]. Precise localization of the epiletogenic zone is critical for epilepsy surgery to remove the epileptic locus maximally effectively without causing neurological dysfunction. High-resolution MRI can be used to detect structural dysfunction caused by hippocampal sclerosis [6]. However, abnormal neuronal discharges sometimes do not occur in the dysfunctional structure. The epileptogenic focus is often not consistent with the structural lesion. Electroencephalography (EEG), in particular preoperative video-EEG (VEEG) and intraoperative electrocorticography (ECoG), can be applied to precisely localize the epileptogenic focus for surgical resection $[7,8]$. Both electroencephalographic techniques have been shown to be safe and effective methods with respect to epileptic patients who undergo surgery [9-11].

In our study, we retrospectively investigated 88 patients with TLE who underwent surgical resection of the epileptogenic structures. The purpose of the 
study was to compare the efficacy and accuracy of VEEG and ECoG in locating the epileptic foci in such patients.

\section{METHODS}

Patients. Eighty-eight subjects $(48$ men and 40 women) with TLE were involved in the study. The average age of the patients was 17 years (range 8 to 38 years). The mean disease duration was 4.8 years (range 3-14 years). Thirty-six patients had a history of febrile seizures before two years old, 12 patients had a history of asphyxia after birth, 12 patients had no history of obvious causes of seizures, and 48 patients exhibited aura symptoms before onset of the seizure, including abdominal discomfort, dizziness, and palpitation. The major clinical manifestations were complex partial seizures in 24 cases $(27.3 \%)$, complex partial seizures evolving to tonico-clonic seizures in 52 cases $(59.1 \%)$, and simple partial seizures with motor signs in 12 cases $(13.6 \%)$. The seizure frequency ranged from 1-2 events per days to 3-4 seizures per month. All patients were treated with antiepileptic medications, but initiation of the seizures was usually not controlled. The patients underwent surgical resection of the anterior temporal lobe and medial temporal lobe structures. As was estimated, 76 patients had hippocampal sclerosis. In 4, 4, 2, and 2 cases, glioma, cavernous hemangioma, hippocampal dysplasia, and traumatic malacia, respectively, were diagnosed. The patients were followed up for a period of one to six years.

Clinical Examination. All patients underwent preoperative VEEG, intraoperative ECoG, and magnetic resonance imaging (MRI). The VEEG examination was performed using a 64-channel Medelec Valor EEG system (Oxford Instruments, Great Britain). The recording electrodes were placed according to the international 10-20 system and attached on the scalp by collodion. A common average reference technique was used to record VEEG for 2-7 days. The ECoG examination was performed on patients during surgery under general anesthesia, before and after surgical resection of the epileptic locus, using a 32-channel Medelec Valor EEG system (Oxford Instruments, Great Britain). Fifteen minutes before intraoperative ECoG, intravenous administration of Propofol was stopped, and inhalation of isoflurane was reduced. After dural incision, an electrode set was placed on the surface of the temporal cortex. The EEG data were first analyzed visually, and epileptiform discharges were identified as spikes, sharp waves, spike-and-slow wave complexes, sharp-and-slow wave complexes, and multispike complexes. A multielectrode set was placed in the hippocampus; the pucture point was located at the middle gyrus of the temporal lobe (50 $\mathrm{mm}$ from the temporal pole, and $35 \mathrm{~mm}$ deep).

We analyzed the patterns, location, and spatial distribution of epileptiform discharges in preoperative VEEG and intraoperative ECoG, and compared differences in the epileptiform waves recorded by these two techniques. The detection rates provided by VEEG and ECoG were also compared.

Patient Outcome. The patient outcome was reported based on the seizure occurrence at the latest followup visit. The outcome was classified into four groups according to the Engel classification system: (i) class I, free of disabling seizures, (ii) class II, rare disabling seizures, (iii) class III, worthwhile improvement, and (iv) class IV, no worthwhile improvement.

Statistical Analysis was performed using SPSS 11.5; the $\chi^{2}$ test was used to compare the difference in the detection rates of epileptic abnormalities between patients examined with ECoG and VEEG. Differences with $P<0.05$ were considered statistically significant.

\section{RESULTS}

Radiological Findings. All patients underwent MRI examination. Fifty-six patients exhibited unilateral atrophy in the hippocampus accompanied by an enlargement of the temporal lobe. Hyperintense signals in the hippocampus were found in 20 patients, and abnormal signals in the temporal lobe and hippocampus were observed in 12 patients.

Eight patients were examined with PET. Metabolism was reduced in the anterior and inferior temporal lobes compared with that in the surrounding cortex, and hypometabolic areas were localized. Forty patients underwent MRS, showing unilateral hippocampal injury or dysfunction.

VEEG Findings. All patients were monitored for more than $24 \mathrm{~h}$. Frequent focal epileptiform discharges were recorded at one side of the temporal lobe during the interictal period in 56 patients. In 20 patients, epileptiform discharges were recorded at both sides of the temporal lobe, with one side predominating over another. In 12 patients, epileptiform discharges were recorded by all recording electrodes, with 
asynchronous discharge at one side of the temporal lobe. Seizure attacks were usually recorded, with epileptiform discharges starting from one side of the temporal lobe.

ECoG Findings. All 88 patients underwent surgical resection (under general anesthesia) of the anterior temporal lobe and medial temporal lobe structures using the standard Spencer method. The operation was performed with ECoG and depth-electrode monitoring (Fig. 1A, B). We focused particularly on the localization of the epileptic abnormality identified by preoperative VEEG. In 64 patients, ECoG identified frequent focal epileptiform discharges in the temporal lobe and interior frontal gyrus. Depth-electrode recordings showed epileptiform discharges in the hippocampus (C). In 24 patients, ECoG showed extensive epileptiform discharges in the left sylvian gyrus of the temporal lobe and in the inferior and middle frontal gyri. No obvious epileptiform discharges were found in depth-electrode recordings in 4 patients.

We compared differences in the detection rates of the epileptic abnormalities between patients examined with ECoG and VEEG. Such abnormalities were detected with VEEG in the epileptogenic focus in 76 of 88 patients $(86.5 \%)$ and in all, with no exception, patients examined with ECoG. Therefore, ECoG showed a significantly higher detection rate than VEEG $(P<0.05)$.

We also compared the differences in spatial distribution of epileptiform discharges detected using intraoperative ECoG and preoperative VEEG. In 52 patients, the observed spatial distribution of epileptiform discharges in the intraoperative ECoG was narrower compared with that detected by preoperative VEEG. In 24 patients, spatial distribution of epileptiform discharges in intraoperative ECoG overlapped that estimated by preoperative VEEG with a consistency of $>80 \%$. In 12 patients, spatial distribution of epileptiform discharges in intraoperative ECoG and preoperative VEEG shared a consistency of 60 to $80 \%$.

After surgery, no epileptiform discharges were observed at the operation or other sites (Fig. 1D). Postoperative pathological analysis of hippocampal tissues showed that hippocampal sclerosis (neural degeneration and glial cell hyperplasia) was manifested in 76 patients. Glioma, cavernous hemangioma, hippocampal dysplasia, and traumatic malacia were found in 4, 4, 2, and 2 cases, respectively.

Follow-up. All patients were treated with antiepileptic medicines during the follow-up period of one to six years. No seizures (Engel class I) were found in 72 patients $(81.8 \%)$. No epileptiform discharges were found in EEGs recorded within this period. Reduced seizure attacks (Engel class II) were found in 12 patients $(13.6 \%)$, with a few epileptiform discharges found in the EEG records. Mild seizures with shorter attack durations (Engel class III) accompanied by epileptiform discharges found in EEG were observed in 4 patients $(4.5 \%)$. Eighty patients $(90.9 \%)$ exhibited clear improvement in their neuropsychological functions.

\section{DISCUSSION}

Temporal lobe epilepsy is the most common type of medically refractory epilepsy. Hippocampal
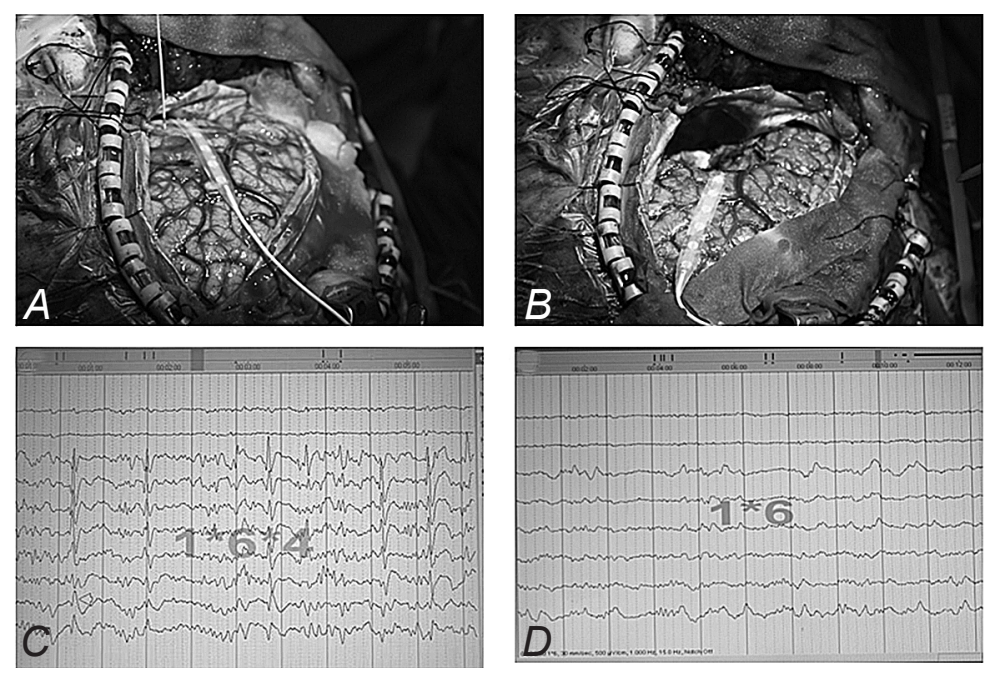

Electrocorticogram (ECoG) and depth-electrode recoding before (A and $\mathrm{C}$ ) and after (B and D) epilepsy surgery. An electrode array was placed on the surface of the temporal cortex to record ECoG, and a fourcontact strip was placed in the hippocampus for depth-electrode recording. Simultaneous epileptiform discharges were recorded form the left temporal lobe and hippocampus before surgery (C). After surgical resection of the anterior and medial temporal lobe structures, epileptiform discharges disappeared (D). B and D) Top two traces are reference ones, while traces 3 to 8 are ECoG records by six electrodes; traces 9 and 10 are depth-electrode records by two contacts.

Електрокортикограми (ЕКоГ) i відведення за допомогою глибинних електродів перед ( $A$ та $C$ ) та після $(B$ та $D)$ хірургічного втручання $з$ приводу епілепсії. 
sclerosis is one of the usual features associated with TLE [12]. Consistent with this feature of TLE, we found that 76 of 88 patients $(86.4 \%)$ suffered from hippocampal sclerosis. This type of pathology is characterized by significant resistance with respect to antiepileptic medicines [13] and is a good indication for surgical treatment [14]. Epilepsy-related surgery can effectively disrupt the epileptogenic network to achieve freedom from seizures. Our study found that 72 patients $(81.8 \%)$ remained seizure-free within the follow-up period of one to six years, suggesting that surgical resection is a rather effective treatment for TLE.

Precise localization of the epileptogenic zone is critical for epilepsy surgery to remove the epileptic locus. Preoperative VEEG and postoperative ECoG are at present often used to localize the epileptogenic locus for surgical resection [7, 8]. Previous studies have shown that VEEG has certain limitations in localizing the epileptogenic zone compared with intracranial ECoG [15, 16]. In agreement with these studies, we found that spatial distribution of epileptiform discharges detected by intraoperative ECoG was more local and adequate in 52 of 88 patients $(59 \%)$ compared with that estimated by preoperative VEEG. Thus, ECoG allows surgeons to more precisely localize the epileptogenic zone compared with VEEG. In 56 patients, frequent focal epileptiform discharges were recorded by VEEG at one side of the temporal lobe and were identified in the temporal lobe and interior frontal gyrus by ECoG and in the hippocampus by depth-electrode recordings. In addition, VEEG showed epileptiform discharges at both sides of the temporal lobe, with one side predominating, in 20 patients. In 12 subjects, such activity was recorded by all recording electrodes, with asynchronous discharges at one side of the temporal lobe. In contrast, ECoG showed that epileptiform discharges were found in these patients in the left sylvian gyrus of the temporal lobe and in the inferior and middle frontal gyri. The spike activity recorded by VEEG exhibited a smaller amplitude and more extensive spatial distribution than that in ECoG, further demonstrating that VEEG is not as sensitive as EcoG in strict localization of the epileptogenic zone.

Video EEG possesses some advantages in detecting epileptogenic focus in epileptic patients. This technique is noninvasive and can record focal electrical activities in the brain without interfering observation of clinical manifestations in patients during seizure attack. Video EEG recordings can be repeatedly played back and thus can be used for repeated studies. Therefore, VEEG can successfully be used to characterize epilepsy and, in such a way, to initially identify epileptogenic focus based on different VEEG features of epilepsy. However, this technique has certain limitations, mainly its relatively low sensitivity to accurately detect the epileptogenic zone. Since VEEG electrodes are placed on the scalp, brain electrical activity recorded by VEEG is affected a number of factors. These records reflect synchronous activity of a great number of neurons and depend on the arrangement of neurons in the cerebral cortex and on the integrity and conductivity of the scalp and the skull. Since the amplitude of electrical activity originating from the brain is attenuated with increasing distance, and the scalp and skull are poor conductors of electricity, neural electrical activity recorded by VEEG undergoes strong decay. In addition, the skull has different thicknesses in its different parts, which can produce variable capacitance and inductance effects. Thus, electrical activity of the brain of VEEG is inevitably distorted. Because of this, it is difficult for VEEG to locate the epileptogenic foci with $100 \%$ accuracy. In contrast, ECoG electrodes are placed directly on the cortical surface. The electrical activity generated by synchronously active neurons can be recorded more directly, without interference from the conductance of the skull and scalp. This is why the amplitude of electrical events recorded by ECoG is much higher than that recorded by VEEG [17, 18]. Therefore, abnormal epileptiform waves can be recorded by ECoG more clearly than by VEEG, and this allows researchers to more accurately display epileptiform discharges in the brain [19].

Clinical evidence shows that simple surgical removal of the structural lesions identified by radiographic imaging does not eliminate seizures in all cases. Therefore, the advantage of ECoG is to repeatedly check out surrounding brain tissues to identify the remaining epileptiform discharges and to further remove the epitleptogenic zone until such discharges disappear or are significantly reduced. In our study, when we identified sharp waves and spikes during intraoperative ECoG, we localized the epileptogenic zone more accurately, determined strictly the distribution of the epileptic foci, and then removed these foci as much as possible without significantly damaging important brain functions. For example, when ECoG identified epileptiform discharges deeply in the temporal lobe, we selectively subjected the hippocampal regions and amygdala to removal. We found that after removal of lesions in 
the temporal lobe (including the hippocampus and amygdala), epileptiform discharges in other brain regions disappeared or were significantly reduced, suggesting that the main epileptogenic foci have been successfully removed. Therefore, ECoG allows surgeons to more precisely locate and remove the epileptogenic foci and to avoid unnecessary damage to the brain.

We found that the spatial distribution of epileptiform discharges estimated by intraoperative ECoG was accurate in 52 patients $(59 \%)$, with a consistency of $>80 \%$ in 24 patients $(27 \%)$, and with a consistency of $60-80 \%$ in 12 patients (14\%), compared with that in preoperative VEEG. The inconsistency in spatial distribution of epileptiform discharges between intraoperative $\mathrm{ECoG}$ and preoperative VEEG suggests that surgeons may have removed the epileptic foci incompletely or excessively without the help of intraoperative ECoG.

In summary, ECoG has obvious advantages over VEEG in epilepsy-related surgery. Compared with VEEG, ECoG allows surgeons to more precisely locate the epileptogenic foci, to more accurately identify their spatial distribution, and to check the efficiency of removal in the course of operation. Thus, ECoG opens possibilities to more adequately remove the above foci and to avoid unnecessary damage to the brain or incomplete removal of pathologically modified brain regions.

All procedures followed were in accordance with the ethical standards of the responsible Committees on human experimentation (institutional and national) and with the Helsinki Declaration of 1975, as revised in 2000 (5). Written informed consent was obtained from all patients included in the study.

The authors of this study, J. Xiang and Yu. Jiang, declare that the research and publication of the results were not associated with any conflicts regarding commercial or financial relations, relations with organizations and/or individuals who may have been related to the study, and interrelations between co-authors of the article.

Дж. Ксіан ${ }^{1}, Ю$. Джіан

ЗАСТОСУВАННЯ ТРИВАЛОЇ ВІДЕОЕЛЕКТРОЕНЦЕФАЛОГРАФІІ ТА ЕЛЕКТРОКОРТИКОГРАФІЇ В ХІРУРГІЧНОМУ ЛІКУВАННІ ТЕМПОРАЛЬНОЇ ЕПІЛЕПСІї

'Друга лікарня Ксіанг'я Центрального південного університету, Чанша (Китай).
Р е 3 ю м е

У перебігу хірургічного лікування 88 пацієнтів 3 темпоральною епілепсією (ТЕ) використовували тривалу преопераційну відеоелектроенцефалографію (ВЕЕГ) та інтраоперативну електрокортикографію (ЕКоГ). Аналізували патерни, локалізацію і просторовий розподіл епілептиформних розрядів, та порівнювали результати використання ВЕЕГ та ЕКоГ. Фокальні епілептиформні розряди, що виникали з великою частотою, були зареєстровані за допомогою ВЕЕГ у 56 пацієнтів унілатерально в темпоральній частці кори, а ЕКоГ дозволяла ідентифікувати такі розряди в темпоральній частці та нижній фронтальній звивині. Подібні розряди відводилися від обох темпоральних часток у 20 пацієнтів та всіма електродами унілатерально від однієї темпоральної частки у 12 пацієнтів. У цих пацієнтів епілептиформні розлади ідентифікувалися за допомогою ЕКоГ у лівій сільвієвій звивині темпоральної частки та в нижній і середній фронтальних звивинах. Просторовий розподіл епілептиформних розрядів був адекватно ідентифікований за допомогою ЕКоГ у 52 (59 \%) пацієнтів; співпадіння 3 даними ВЕЕГ складало більше $80 \%$ у 24 (27\%) пацієнтів і було в межах 60-80\% у 12 (14\%). Судоми були усунуті у 72 (81.8\%) пацієнтів; стан хворих був істотно поліпшений у 12 (13.6\%) випадках і не змінювався у чотирьох (4.5\%) випадках. Наші дані свідчать про помітні переваги ЕКоГ над ВЕЕГ в аспекті можливості визначення точної локалізації епілептогенних фокусів, i, таким чином, ïi застосування є доцільним при хірургічному лікуванні TE.

\section{REFERENCES}

1. F. Semah, M. C. Picot, C. Adam, et al., "Is the underlying cause of epilepsy a major prognostic factor for recurrence?" Neurology, 51, 1256-1262 (1998).

2. J. F. Tellez-Zenteno and L. Hernandez-Ronquillo, "A review of the epidemiology of temporal lobe epilepsy," Epilepsy Res. Treat., 2012, Article ID 630853 (2012).

3. W. Penfield, "Temporal lobe epilepsy," Br. J. Surg., 41, $337-$ 343 (1954).

4. S. Wiebe, W. T. Blume, J. P. Girvin, and M. Eliasziw, "A randomized, controlled trial of surgery for temporal-lobe epilepsy," New Engl. J. Med., 345, 311-318 (2001).

5. M. M. Zaatreh, K. S. Firlik, D. D. Spencer, and S. S. Spencer, "Temporal lobe tumoral epilepsy: characteristics and predictors of surgical outcome," Neurology, 61, 636-641 (2003).

6. G. D. Jackson, S. F. Berkovic, B. M. Tress, et al., "Hippocampal sclerosis can be reliably detected by magnetic resonance imaging," Neurology, 40, 1869-1875 (1990).

7. R. L. Kutsy, "Focal extratemporal epilepsy: clinical features, EEG patterns, and surgical approach," J. Neurol. Sci., 166, 1-15 (1999).

8. M. Javidan, "Electroencephalography in mesial temporal lobe epilepsy: a review," Epilepsy Res. Treat., 2012, Article ID 637430 (2012).

9. P. O. da Conceicao, G. M. de Araujo Filho, L. Mazetto, et al., "Safety of video-EEG monitoring and surgical outcome in patients with mesial temporal sclerosis and psychosis of 
epilepsy," Seizure, 21, 583-587 (2012).

10. N. Luther, E. Rubens, N. Sethi, et al., "The value of intraoperative electrocorticography in surgical decision making for temporal lobe epilepsy with normal MRI," Epilepsia, 52, 941-948 (2011).

11. A. Kuruvilla and R. Flink, "Intraoperative electrocorticography in epilepsy surgery: useful or not?" Seizure, 12, 577-584 (2003).

12. J. G. Jefferys, "Hippocampal sclerosis and temporal lobe epilepsy: cause or consequence?" Brain, 122, Part 6, 10071008 (1999).

13. A. Pitkanen and T. P. Sutula, "Is epilepsy a progressive disorder? Prospects for new therapeutic approaches in temporal-lobe epilepsy," Lancet Neurol., 1, 173-181 (2002).

14. M. D. Smyth, D. D. Limbrick Jr., J. G. Ojemann, et al., "Outcome following surgery for temporal lobe epilepsy with hippocampal involvement in preadolescent children: emphasis on mesial temporal sclerosis," J. Neurosurg., 106, 205-210 (2007).

15. L. F. Quesney, M. Constain, T. Rasmussen, et al., "Presurgical EEG investigation in frontal lobe epilepsy," Epilepsy Res., Suppl., 5, 55-69 (1992).

16. L. F. Quesney and A. Olivier, "Pre-operative EEG evaluation in frontal lobe epilepsy," Acta Neurol. Scand., Suppl., 117, 6172 (1988).

17. K. Hashiguchi, T. Morioka, F. Yoshida, et al., "Correlation between scalp-recorded electroencephalographic and electrocorticographic activities during ictal period," Seizure, 16, 238-247 (2007)

18. J. X. Tao, A. Ray, S. Hawes-Ebersole, and J. S. Ebersole, "Intracranial EEG substrates of scalp EEG interictal spikes," Epilepsia, 46, 669-676 (2005).

19. D. L. Keene, S. Whiting, and E. C. Ventureyra, "Electrocorticography," Epilept. Disord., 2, 57-63 (2000). 